\title{
Pemanfaatan Instagram dalam Sosialisasi Gerakan Selamatkan Pejalan Kaki

\author{
(Studi pada Komunitas Koalisi Pejalan Kaki)
}

\author{
Lilis Ramadhanti, Yugih Setyanto \\ lilisdanti@gmail.com,yugihs@fikom.untar.ac.id
}

Fakultas Ilmu Komunikasi Universitas Tarumanagara

\begin{abstract}
This study discusses the use of Instagram by Koalisi Pejalan Kaki community in disseminating the Save Walkers movement. This research was conducted using a qualitative descriptive research approach with a case study research method. The data used in this study consisted of primary data and secondary data. Primary data in the form of Instagram posts@ @oalisipejalankaki account and information obtained from interviews with several informants. While secondary data in the form of data obtained from books and other sources. The theory used consists of communication, group communication, new media, and community. Data collection techniques used are interviews, observation, literature study and online data search. The results of this study indicate that Koalisi Pejalan Kaki community utilizes Instagram social media as a forum to socialize the Save Walkers movement, thereby creating community awareness for pedestrians.
\end{abstract}

Keywords: Community, new media, social media, Instagram

\begin{abstract}
Abstrak
Penelitian ini membahas mengenai pemanfaatan Instagram oleh komunitas Koalisi Pejalan Kaki dalam mensosialisasikan gerakan Selamatkan Pejalan Kaki. Penelitian ini dilakukan dengan menggunakan pendekatan penelitian deskriptif kualitatif dengan metode penelitian studi kasus. Data yang digunakan dalam penelitian ini terdiri dari data primer dan data sekunder. Data primer berupa postingan Instagram akun@koalisipejalankaki dan informasi yang diperoleh dari hasil wawancara dengan beberapa informan. Sedangkan data sekunder berupa data yang diperoleh dari buku dan sumber lain. Teori yang digunakan terdiri dari komunikasi, komunikasi kelompok, media baru, dan komunitas. Teknik pengumpulan data yang digunakan yaitu wawancara, observasi, studi kepustakaan dan penelusuran data online. Hasil dari penelitian ini menunjukkan bahwa komunitas Koalisi Pejalan Kaki memanfaatkan Instagram sebagai media dalam mensosialisasikan gerakan Selamatkan Pejalan Kaki sehingga menciptakan kepedulian masyarakat kepada pejalan kaki.
\end{abstract}

Kata Kunci: Komunitas, media baru, media sosial, Instagram

\section{Pendahuluan}

Manusia pada dasarnya adalah makhluk sosial yang tidak dapat hidup tanpa bantuan orang lain, oleh karena itu komunikasi sangat diperlukan untuk membentuk suatu interaksi sosial. Interaksi sosial dapat terjadi dalam hubungan antara individu dengan individu, individu dengan kelompok, maupun kelompok dengan kelompok. Pada dasarnya komunikasi telah menjadi suatu kebutuhan pokok bagi manusia. Hal 
tersebut dikarenakan setiap perilaku manusia memiliki potensi terjadinya komunikasi, baik komunikasi secara verbal maupun non-verbal.

Dengan adanya teknologi mempermudah manusia dalam berkomunikasi dan mencari informasi. Perkembangan teknologi yang pesat melahirkan suatu era komunikasi interaktif yang ditandai dengan kemunculan internet. Dengan adanya internet, masyarakat dapat menerima informasi secara cepat tanpa terhalang jarak dan waktu, serta menjangkau semua kalangan masyarakat (Tamburaka, 2013:73).

Berdasarkan data yang telah dirangkum oleh Asosiasi Penyelenggara Jasa Internet Indonesia (APJII) mengungkapkan pengguna internet di Indonesia pada tahun 2017 mencapai 143,26 juta jiwa pengguna (https://apjii.or.id/survei2017, diakses pada tanggal 30 Agustus 2018 pukul 14.30 WIB).

Kehadiran internet berdampak pada munculnya beberapa media baru atau yang dikenal dengan istilah new media. Media sosial belakangan ini menjadi media baru yang digemari oleh masyarakat Indonesia. Salah satu media sosial yang sedang populer di Indonesia adalah Instagram. Dengan adanya fungsi Instagram tidak hanya digunakan untuk kepentingan individual saja, namun seringkali dimanfaatkan sebagai penggerak tumbuhnya gerakan sosial baru di masyarakat. Instagram menjadi wadah berkumpulnya suatu komunitas untuk mempermudah manusia berinteraksi dan berkomunikasi.

Melalui visi dan misi yang mereka miliki, diantaranya menyediakan jalur pejalan kaki yang layak, aman, nyaman dan tertib, serta melihat banyaknya respon masyarakat, maka komunitas ini membuat suatu gerakan "Selamatkan Pejalan Kaki" yang bertujuan mengajak masyarakat untuk peduli terhadap lingkungan sekitar terutama dalam menghargai hak pejalan kaki.

Koalisi Pejalan Kaki adalah komunitas yang memiliki tujuan untuk memperjuangkan hak-hak para pejalan kaki di Indonesia. Komunitas ini berdiri sejak tanggal 25 Juni 2011 oleh beberapa inisiator yang merupakan pengguna jasa angkutan umum Kereta Rel Listik (KRL) atau commuterline. Pembentukan komunitas ini didasari atas keprihatinan akan hak-hak pejalan kaki yang seringkali terabaikan, diantaranya adalah minimnya fasilitas umum pejalan kaki, hingga penyalahgunaan trotoar yang seringkali beralih fungsi menjadi jalur lintasan kendaraan, tempat berjualan pedagang kaki lima dan tempat parkir liar (https://megapolitan.kompas.com/read/2014/08/11/16134001/Mengenal.Lebih.Dekat. Koalisi.Pejalan.Kaki.di.Jakarta, diakses pada tanggal 31 Agustus 2018 pukul 17.00 WIB).

Pada saat ini Koalisi Pejalan Kaki telah membuat akun komunitas online melalui Instagram yang telah diikuti oleh lebih dari tiga puluh ribu pengikut (follower) (https://instagram.com/koalisipejalankaki, diakses pada tanggal 2 Desember 2018 pukul 17.55 WIB). Melalui pemanfaatan media sosial, Koalisi Pejalan Kaki menggunakan Instagram sebagai media dalam mensosialisasikan gerakan Selamatkan Pejalan Kaki sehingga menciptakan kepedulian masyarakat kepada pejalan kaki.

Dalam penelitian ini penulis menggunakan teori yang berkaitan dengan studi Ilmu Komunikasi, yaitu teori komunikasi, komunikasi kelompok, media baru, dan komunitas. Menurut Harlod D. Laswell (dalam Soemanagara, 2012:80) mengemukakan definisi komunikasi adalah sebuah kegiatan yang menggunakan saluran-saluran tertentu untuk menjawab pertanyaan Who Says What, in Which Channel To Whom, With What Effect, and In which Channel. Saluran komunikasi ini yang kemudian dapat diwujudkan melalui penggunaan sebuah media. Teori 
komunikasi tentunya memiliki hubungan yang erat dengan penelitian penulis, dimana pertukaran informasi yang terjadi antara komunitas Koalisi Pejalan Kaki dengan pengikutnya (follower) terjadi melalui media sosial Instagram.

Menurut Deddy Mulyana (2005:177) mendefinisikan komunikasi kelompok adalah komunikasi yang terjadi di antara sekumpulan orang yang memiliki tujuan bersama, yaitu saling berinteraksi, mengenal satu sama lain, dan memandang mereka sebagai bagian dari kelompok. Yang terkait dalam penelitian penulis yaitu Koalisi Pejalan Kaki dikategorikan sebagai suatu kelompok yang memiliki tujuan bersama dan menganggap follower di Instagram sebagai bagian dari anggota kelompoknya.

Berdasarkan pendapat McQuail (2012:44) mengungkapkan bahwa media baru adalah seperangkat teknologi yang digunakan sebagai sarana komunikasi sehingga antara individu dengan individu dapat saling terhubung. Di dalam teori media baru, terdapat teori media sosial yang diungkapkan oleh Judy Motion (2016:17) dalam buku "Social Media and Public Relations" mendefinisikan media sosial sebagai medium di internet yang memungkinkan penggunanya untuk saling berinteraksi dan berkomunikasi dengan pengguna lainnya, serta membangun hubungan sosial diantara orang-orang yang memiliki minat terhadap isu tertentu. Salah satu fungsi media sosial yang paling terlihat dalam penelitian ini adalah membangun interaksi lebih dekat dengan khalayak.

Dengan hadirnya media sosial memiliki peran penting sebagai agen sosialisasi. Saat ini, media sosial dapat digunakan sebagai media pembentukan cara pandang, tindakan, dan pola pikir untuk mencapai tujuan utama sosialisasi, sehingga dapat ikut serta berpartisipasi dalam masyarakat (https://news.detik.com/kolom/d3943017/waras-bermedia-sosial, diakses pada tanggal 27 September 2018 pukul 22.15 WIB). Dalam hal ini, internet telah membentuk gerakan menjadi jejaring tersendiri dalam jaringan media sosial.

Salah satu media sosial yang populer di Indonesia saat ini adalah Instagram. Menurut Aditya (dalam Jurnal Jom FISIP Volume 2 No. 2, 2015:3) mengungkapkan Instagram adalah aplikasi yang memungkinkan penggunanya mengirimkan informasi secara cepat dalam bentuk foto atau video yang dilengkapi dengan fitur filter dan edit.

Selain itu, menurut Bambang dalam Aditya (Jurnal Jom FISIP Volume 2 No 2, 2015:3) terdapat beberapa fitur-fitur dalam media sosial Instagram yang juga menjadi indikator dalam penelitian ini, diantaranya hashtag, caption, repost, Instagram story, geotag, follow, like, comment dan mention. Teori Media Baru berkaitan dengan penelitian penulis, dalam hal ini komunitas Koalisi Pejalan Kaki memanfaatkan Instagram sebagai media komunikasi bagi komunitas, khususnya dalam mensosialisasi gerakan Selamatkan Pejalan Kaki. Melalui pemanfaatan Instagram dapat membantu menyampaikan pesan-pesan sosial kepada pengikutnya.

Menurut Wenger (2002:4) komunitas adalah sekumpulan orang yang saling berbagi masalah, perhatian atau kegemaran terhadap suatu topik dan juga ingin memperdalam pengetahuan serta keahlian mereka dengan cara saling berinteraksi secara terus-menerus. Dalam penelitian ini, Koalisi Pejalan Kaki terdiri dari sekumpulan orang yang memiliki suatu kepentingan yang sama, yaitu untuk berbagi informasi melalui pemanfaatan Instagram dalam mensosialisasikan gerakan Selamatkan Pejalan Kaki yang bermanfaat untuk mengedukasi masyarakat sehingga menciptakan kepedulian masyarakat kepada pejalan kaki.

Berdasarkan uraian diatas maka penulis tertarik untuk melakukan penelitian mengenai bagaimana pemanfaatan Instagram dalam sosialisasi gerakan Selamatkan 
Pejalan Kaki (studi pada komunitas Koalisi Pejalan Kaki). Oleh sebab itu dapat diketahui berdasarkan latar belakang penelitian tersebut, maka tujuan penelitian ini adalah untuk mengetahui bagaimana pemanfaatan Instagram oleh komunitas Koalisi Pejalan Kaki dalam mensosialisasikan gerakan Selamatkan Pejalan Kaki.

\section{Metode Penelitian}

Penelitian ini menggunakan pendekatan deskriptif kualitatif dengan metode penelitian studi kasus. Menurut Muhammad Idrus (2009:23-24) mendefinisikan penelitian kualitatif adalah metode yang digunakan untuk meneliti informan sebagai subjek penelitian dengan cara berinteraksi secara langsung, mengenal secara mendalam dunia kehidupan informan, serta mengamati alur kehidupan informan secara wajar. Sedangkan, menurut Sugiyono (2013:3) dalam buku "Metode Penelitian Pendidikan Pendekatan Kuantitatif, Kualitatif" menjelaskan metode penelitian deskriptif adalah suatu metode yang bertujuan untuk meneliti keadaan atau kondisi tertentu dan kemudian hasilnya disajikan dalam bentuk laporan penelitian.

Menurut Robert K. Yin (2013:1) dalam buku "Studi Kasus: Sains \& Metode" menjelaskan definisi studi kasus adalah suatu metode penelitian ilmu sosial yang menjawab pertanyaan how dan why terkait peristiwa-peristiwa yang diteliti, serta fokus penelitiannya terletak pada fenomena kontemporer di masyarakat.

Data dalam penelitian ini mengacu pada teori yang dijadikan alat penelitian utama sejak memilih dan menemukan masalah, hingga proses pengujian data atau analisis data. Untuk memperkuat informasi yang dikumpulkan sebagai data penelitian, maka metode pengumpulan data yang digunakan oleh penulis dalam penelitian ini dilakukan dengan cara wawancara, observasi, studi kepustakaan dan penelusuran data online. Terdapat lima narasumber dalam penelitian ini yaitu sebagai berikut:

1. Informan pertama adalah Anthony Ladjar (43 tahun) selaku salah satu dari tujuh pendiri komunitas Koalisi Pejalan Kaki yang masih aktif berperan dalam komunitas.

2. Informan kedua adalah Alfred Sitorus (42 tahun) selaku ketua dan pengelola akun Instagram Koalisi Pejalan Kaki, penulis memilih narasumber karena beliau memiliki banyak informasi mengenai Koalisi Pejalan Kaki.

3. Informan ketiga adalah Ali (21 tahun) berperan sebagai follower Instagram Koalisi Pejalan Kaki selama satu tahun dan aktif berperan sebagai volunteer komunitas.

4. Informan keempat adalah Noval (21 tahun) selaku perwakilan dari Qlue Smart City yang sedang bekerjasama dengan Koalisi Pejalan Kaki untuk membuat suatu campaign yaitu anti parkir liar, pernah berpartisipasi dalam aksi yang dilakukan oleh komunitas, serta berperan sebagai follower Instagram Koalisi Pejalan Kaki selama dua bulan.

5. Informan kelima adalah Nukman Luthfie selaku pakar media sosial, penulis memilih narasumber karena beliau memiliki banyak pengetahuan mengenai media sosial dan mengetahui tentang topik penelitian penulis, seperti yang dapat diketahui bahwa sepuluh tahun terakhir beliau banyak menjadi narasumber sebagai pakar media sosial di beberapa media, seperti televisi, radio, koran, dan juga media online. 
Lilis Ramadhanti, Yugih Setyanto: Pemanfaatan Instagram dalam Sosialisasi Gerakan Selamatkan Pejalan Kaki (Studi pada Komunitas Koalisi Pejalan Kaki)

Dalam penelitian ini penulis menggunakan teori sebagai alat penelitian, dimulai pada saat menemukan masalah, hingga saat melakukan pengamatan di lapangan sampai dengan pengujian data (Bungin, 2011:24).

\section{Hasil Temuan dan Diskusi}

Komunikasi menurut Harlod D. Laswell (dalam Soemanagara, 2012:80) adalah sebuah kegiatan yang menggunakan saluran-saluran tertentu untuk menjawab pertanyaan Who Says What, in Which Channel To Whom, With What Effect, and In which Channel. Saluran komunikasi ini yang kemudian dapat diwujudkan melalui penggunaan sebuah media. Hal tersebut sejalan dengan komunitas Koalisi Pejalan Kaki yang memanfaatkan Instagram sebagai saluran komunikasi bagi komunitasnya.

Dalam hasil wawancara penulis dengan admin Instagram Koalisi Pejalan Kaki, terungkap bahwa pada awalnya media sosial yang digunakan oleh komunitas adalah Facebook dan Twitter. Namun, karena perkembangan teknologi yang sangat pesat sehingga muncul media sosial baru, yaitu Instagram yang cukup diminati oleh masyarakat khususnya di kawasan Asia. Dan juga respon publik melalui Instagram lebih cepat dibandingkan dengan media sosial lainnya. Hal tersebut yang membuat komunitas Koalisi Pejalan Kaki memilih Instagram sebagai sarana komunikasi bagi komunitasnya. Pada akun Instagram tersebut lebih banyak memposting hal-hal yang berhubungan dengan aktivitas pejalan kaki, pelanggaran-pelanggaran di jalan raya yang berkaitan dengan pejalan kaki dan ajakan untuk menggunakan sarana transportasi umum.

Berdasarkan wawancara yang penulis lakukan dengan salah satu follower Instagram Koalisi Pejalan Kaki, terungkap bahwa Instagram telah menjadi media komunikasi yang efisien antara Komunitas Koalisi Pejalan Kaki untuk berkomunikasi dengan masyarakat. Hal tersebut dapat dilihat dari proses interaksi yang dibangun oleh komunitas Koalisi Pejalan Kaki dengan membuka ruang bagi para follower-nya untuk saling berinteraksi, berkomunikasi dan dapat meyalurkan aspirasi.

Akan tetapi admin Instagram Koalisi Pejalan Kaki sendiri mengatakan bahwa ia cenderung lebih selektif dalam membalas komentar yang ada di postingan Instagram untuk mempertahankan kenetralan komunitasnya. Komentar atau masukan yang ada lebih sifatnya di tampung untuk menjadi data base komunitas untuk melakukan evaluasi kedepannya. Sehingga melalui pemanfaatan Instagram tersebut dapat terlihat arah komunikasi yang terbangun.

Instagram termasuk salah satu media sosial yang sedang populer digunakan oleh beberapa komunitas saat ini. Dalam penelitian ini, komunitas Koalisi Pejalan Kaki memanfaatkan media sosial Instagram sebagai media sosialisasi gerakan Selamatkan Pejalan Kaki.

Menurut Bambang dalam Aditya (Jurnal Jom FISIP Volume 2 No.2, 2015:3) terdapat beberapa fitur-fitur dalam media sosial Instagram yang menjadi indikator dalam penelitian ini, diantaranya hashtag, caption, repost, geotag, follow, Instagram Stoty, like, comment dan mention. Dan terdapat istilah yang digunakan untuk pertemanan, yaitu following dan follower. Following artinya anda mengikuti pengguna lain, sedangkan follower berarti pengguna lain yang mengikuti anda.

Menurut Puntoadi (2011:5) menjelaskan bahwa terdapat empat fungsi media sosial, yaitu 
a. Membangun Personal Branding : Media sosial memungkinkan penggunanya untuk saling berkomunikasi, berdiskusi, dan membentuk suatu popularitas di media sosial. Berdasarkan hasil wawancara dengan salah satu follower mengatakan bahwa Instagram Koalisi Pejalan Kaki dapat menjadi alat edukasi masyarakat walaupun tidak bertatap muka secara langsung, sehingga Instagram menjadi media yang efisien dalam penyampaian ide-ide komunitas.

b. Membangun Interaksi Lebih Dekat dengan Khalayak: Konten komunikasi dalam media sosial sifatnya personal, sehingga dapat membangun sebuah ketertarikan dan interaksi yang lebih mendalam dengan khalayaknya. Berdasarkan hasil wawancara dengan salah satu follower mengungkapkan bahwa konten-konten Instagram Koalisi Pejalan Kaki selalu mengutamakan informasi seputar aktifitas pejalan kaki, sehingga dari hal tersebut muncul ketertarikan dari para pengguna Instagram untuk mem-follow dan mengamati setiap konten media sosialnya.

c. Perbincangan: Media sosial memungkinkan terjadi komunikasi secara dua arah. Hal ini sejalan dengan komunitas Koalisi Pejalan Kaki, dimana media sosial Instagram komunitas menjadi wadah untuk berkomunikasi dan berinteraksi dengan pengikutnya.

d. Keterhubungan: Media sosial mampu menghubungkan antar pengguna yang satu dengan pengguna lainnya melalui fitur-fitur yang disediakan. Hal ini sejalan dengan komunitas Koalisi Pejalan Kaki dalam memanfaatkan fiturfitur yang ada di Instagram untuk menghubungkan antar pengguna yang satu dengan lainnya, diantaranya fitur hashtag, caption, repost, Instagram Story, geotag, follow, like, comment dan mention. Hal tersebut diperjelas oleh pernyataan dari salah satu follower Instagram Koalisi Pejalan Kaki yang mengatakan bahwa konten-konten Instagram Koalisi Pejalan Kaki dapat dengan mudah ditemukan melalui fitur hashtag sehingga video atau foto Koalisi Pejalan Kaki dapat dengan mudah disebarkan.

Komunitas Koalisi Pejalan Kaki memanfaatkan Instagram sebagai sarana untuk mensosialisasikan gerakan Selamatkan Pejalan Kaki, dimana dapat diketahui berdasarkan hasil wawancara dengan ketua komunitas Koalisi Pejalan Kaki yang mengatakan bahwa sosialisasi yang dilakukan oleh komunitas lebih dikenal dengan istilah aksi. Dan aksi tersebut dilakukan berdasarkan aduan publik melalui Instagram. Sosialisasi tersebut dapat direalisasikan melalui pemanfaatan fitur-fitur yang disediakan seperti hashtag, caption, repost, Instagram Story, geotag, follow, like, comment dan mention, sehingga dapat membantu komunitas Koalisi Pejalan Kaki membangun komunikasi secara efisien dengan para follower-nya.

\section{Simpulan}

Berdasarkan penelitian yang telah dilakukan, maka penulis menyimpulkan bahwa pemanfaatan Instagram oleh komunitas Koalisi Pejalan Kaki dalam mensosialisasikan gerakan Selamatkan Pejalan Kaki adalah sebagai berikut:

a. Komunitas Koalisi Pejalan Kaki memilih Instagram sebagai sarana untuk membangun interaksi dan komunikasi secara virtual antar pengguna Instagram yang tertarik dengan aktifitas pejalan kaki.

b. Melalui pemanfaatan Instagram berperan dalam membangun kepercayaan publik terhadap komunitas. 
c. Komunitas Koalisi Pejalan Kaki membuka ruang bagi para follower-nya untuk saling berinteraksi, berkomunikasi dan menyalurkan aspirasi.

d. Komunitas Koalisi Pejalan Kaki lebih cenderung selektif dalam membalas komentar yang ada untuk mempertahankan kenetralan komunitasnya.

e. Proses komunikasi melalui Instagram dilakukan dengan memanfaatkan fitur-fitur yang disediakan seperti, hashtag, caption, repost, Instagram Story, geotag, follow, like, comment dan mention, sehingga dapat membantu komunitas Koalisi Pejalan Kaki membangun komunikasi secara efisien dengan para follower-nya.

f. Komunitas Koalisi Pejalan Kaki memanfaatkan Instagram sebagai sarana untuk mensosialisasikan gerakan Selamatkan Pejalan Kaki, sehingga menciptakan kepedulian masyarakat kepada pejalan kaki, hal tersebut dapat terlihat melalui banyaknya respon masyarakat berupa komentar, like, maupun kiriman foto atau video di Instagram.

\section{Ucapan Terima Kasih}

Peneliti mengucapkan terima kasih yang sebesar-besarnya kepada semua pihak yang telah berperan membantu dalam penyusuan Skripsi ini diantaranya, komunitas Koalisi Pejalan Kaki, follower Instagram Koalisi Pejalan Kaki, pakar media sosial, dan sahabat-sahabat penulis selama masa perkuliahan.

\section{Daftar Pustaka}

Aditya, Rangga, (2015). Pengaruh Media Sosial Instagram Terhadap Minat Fotografi Pada Komunitas Fotografi PekanBaru. Jurnal Jom FISIP Volume 2 No. 2, Oktober 2015.

Retrieved from https://jom.unri.ac.id/index.php/JOMFSIP/article/view/5880

Ayuningtyas, F., \& Abdullah, A. (2018). Kognisi Sosial Melalui Situs Jejaring

Youtube Pada Komunitas Online (Studi Kasus pada Komunitas Online LinkPictureID). Jurnal Komunikasi, 9(2), 137-150. Retrieved from https://journal.untar.ac.id/index.php/komunikasi/article/view/1076

Azeharie, S., \& Sari, W. (2015). Penyingkapan Diri Ibas Yudhoyono Dalam Instagram Dan Reaksi Ani Yudhoyono Terhadap Postingan Instagram Ibas. Jurnal Komunikasi, $\quad 7(1), \quad 108-117 . \quad$ Retrieved from https://journal.untar.ac.id/index.php/komunikasi/article/view/11

Bungin, Burhan. (2011). Penelitian Kualitatif: Komunikasi, Ekonomi, Kebijakan Publik dan Ilmu Sosial Lainnya. Jakarta: Kencana.

Idrus, Muhammad. (2009). Metode Penelitian Ilmu Sosial. Jakarta: Erlangga.

McQuail, Dennis. (2012). Teori Komunikasi Massa: Edisi 6 Buku 2. Jakarta: Salemba Humanika.

Motion, Judy, Heath Robert L and Leitch Shirley. (2016). Social Media and Public Relations. New York: Routledge.

Mulyana, Deddy. (2005). Ilmu Komunikasi Sebuah Pengantar. Bandung: Remaja Rosdakarya.

Puntoadi, Danis. (2011). Menciptakan Penjualan Melalui Social Media. Jakara: PT. Elex Komputindo.

Soemanagara. (2012). Strategic Marketing Communication. Bandung: Alfabeta.

Sugiyono. (2013). Metode Penelitian Pendidikan Pendekatan Kuantitatif, Kualitatif, dan $R \& D$. Bandung: Alfabeta. 
Tamburaka, Apriadi. (2013). Literasi Media: Cerdas Bermedia Khalayak Media Massa. Jakarta: PT. Rajagrafindo Persada.

Wenger, Etienne et al. (2002). Cultivating Communities of Practice. Harvard Business School Press. 